\title{
JOURNALISTIC CONTENT CURATION AND NEWS LIBRARIANSHIP: DIFFERENTIAL CHARACTERISTICS AND NECESSARY CONVERGENCE
}

Curación periodística y documentación periodística: características diferenciales y convergencia necesaria

\author{
Javier Guallar and Lluís Codina
}

Nota: Este artículo se puede leer en español en:

http://www.elprofesionaldelainformacion.com/contenidos/2018/jul/07_esp.pdf

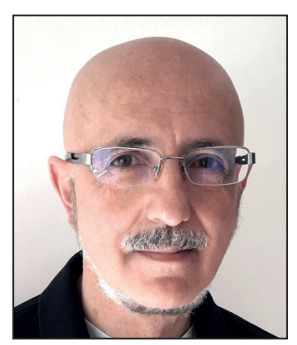

Javier Guallar holds a PhD in Information and Documentation from the Universitat de Barcelo$n a(U B)$. He is a professor in the Department of Library Science, Documentation and Audiovisual Communication of the UB where he directs the postgrad course Social Media Content. Dr. Guallar is a teaching collaborator in the Information Sciences Studies and Communication of the Universitat Oberta de Catalunya (UOC). He is a content curator trainer at loscontentcurators.com, deputy director of the journal El profesional de la información and director of the book collections EI profesional de la información and EPI Scholar published by Editorial UOC. He has previously been a news librarian in several media, and an associate professor at the Universitat Ramon Llull (URL) and at the Universitat Internacional de Catalunya (UIC). He is coauthor of the books Prensa digital y bibliotecas (2010), El content curator (2013) and Calidad en sitios web (2016).

http://orcid.org/0000-0002-8601-3990

Universitat de Barcelona Departament de Biblioteconomia, Documentació i Comunicació Audiovisual Centre de recerca en Informació, Comunicació i Cultura (CRICC) Melcior de Palau, 140. 08014 Barcelona, Spain jguallar@gmail.com

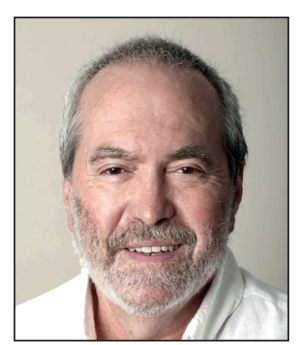

Lluís Codina is a professor at the Facultad de Comunicación of the Universitat Pompeu Fabra, Barcelona. He teaches in the degrees of Journalism and Audiovisual Communication. He is coordinator of the Master's Degree in Social Communication (MUCS) of the Communication Department. $\mathrm{He}$ is part of the academic staff and teaches also in the Online University Masters in Digital Documentation and Search Engines, of the Instituto de Educación Continua. He is a promoter member of the research group in Digital Documentation and Interactive Communication (DigiDoc), and coordinator of its Research Seminar. As a member of the DigiDoc group, he is part of the Journalism Research Unit, a consolidated group recognized by the Generalitat de Catalunya. Dr. Codina has published numerous research articles and several books.

https://orcid.org/0000-0001-7020-1631

Universitat Pompeu Fabra Departament de Comunicació Roc Boronat, 138. 08018 Barcelona, Spain Iluis.codina@upf.edu

\begin{abstract}
Based on a systematic review of the literature on journalistic content curation and news librarianship, the paper puts forward a clarification of the two concepts. Profiles for each of the two disciplines are set out, together with common aspects for comparison to identify their similarities and differences. Based on the comparison, the paper argues for the convergence of the two disciplines, finding that each is vital to safeguarding the social functions performed in the press coverage of current events, including the essential function of user-generated content.
\end{abstract}

\section{Keywords}

Systematic reviews; Content curation; News librarianship; Journalistic content curation; News curation; Journalism; Journalists; News librarians; Curators. 


\section{Resumen}

A partir de una revisión sistematizada de la bibliografía sobre curación de contenidos y sobre documentación periodística, se presenta una propuesta de clarificación conceptual de ambos conceptos. Se establecen perfiles para cada una de las dos disciplinas, así como ejes de comparación comunes que facilitan señalar las similitudes y las diferencias, para concluir a favor de la convergencia de ambas disciplinas. El motivo es que ambas son necesarias para garantizar las funciones sociales de la prensa de cobertura de la actualidad, de las que forman parte esencial los contenidos generados por los usuarios.

\section{Palabras clave}

Revisiones sistematizadas; Curación de contenidos; Documentación periodística; Curación de contenidos periodística; Periodismo; Periodistas; Documentalistas; Curadores.

Guallar, Javier; Codina, Lluís (2018). "Journalistic content curation and news librarianship: Differential characteristics and necessary convergence". El profesional de la información, v. 27, n. 4, pp. 778-791.

https://doi.org/10.3145/epi.2018.jul.07

\section{Introduction}

This paper ${ }^{1}$ sets out to analyse the relationship between the concepts of journalistic content curation and news librarianship, establishing their differences and their points in common based on well-established findings in the academic literature on the two concepts.

The paper argues that the two concepts correspond to two specialities or professional practices in infomediation that are distinct from one another but closely linked. As often happens in any relationship between a newly emerging concept (curation) and a concept that comes from a long-standing academic and professional tradition (librarianship), the relationship between the two is marked by fuzziness, uncertainty and misunderstanding.

Given the importance of conceptual clarification for the advancement of a discipline and the resulting impact that clarity can have on the development of professional competencies, the paper aims to delve deeply into the relationships, divergences and convergences that exist between the two concepts in order to consider the function of journalistic content curation in relation to news librarianship and journalism in general and to identify the chief implications not only for media professionals, especially journalists and media librarians or researchers, but also for media scholars and for the training of journalism students and their peers in other undergraduate communication and information degrees.

\section{Method}

Using a classification of research aims and methods (Thyer, 2010; Creswell, 2012; Ferran-Ferrer et al., 2017; Guallar et al., 2017), the present study may be viewed as a case of theoretical research because of its method. At the same time, it also has a qualitative orientation (Ravitch; Mittenfelner-Carl, 2015) and makes use of research techniques typical of systematic reviews (Booth; Sutton; Papaioannou, 2016).

However, while the study is theoretical in its aim (Thyer, 2010), more specifically exploratory and descriptive (Creswell, 2012), it must be added that research in the in- formation and communication sciences often has a strong component of practical application. Because this is the intention in the present case, the aim of the study can also be regarded as applied theoretical research.

As any theoretical proposal must be underpinned by a review of the previously published literature, we have started with a systematic review (Booth; Sutton; Papaioannou, 2016) of the two key objects of study: news librarianship and content curation in journalism.

First, news librarianship is a long-standing speciality that is the subject of an extensive body of research by academics in information science and communications. As a result, the review strategy has been to select texts viewed as classics or touchstones in the field, giving special attention to studies that analyse new trends, viewpoints or future prospects for information science in the media and have appeared in the past ten years (since 2008). The selection of literature draws on the expert criteria of the paper's authors, who have a track record in research on the subject.

Second, content curation as it applies to journalism has been given a different treatment because it is an emerging concept or speciality. In this case, therefore, the review seeks to be more thorough and comprehensive. To that end, our steps include:

a) First, carrying out searches and setting up alerts in two academic secondary sources: Scopus (Elsevier) and Google Scholar. Scopus, which has indexed roughly 18,000 academic journals since 2001, was chosen for its high degree of representation of the social sciences and its good search features, which permit users to limit queries to key words. Google Scholar was chosen because its coverage is much broader and it includes not only journals but also books and other academic materials. In addition, its alerts and suggestions have been very useful in locating a number of references. We used the search terms listed below in English and in Spanish:

"content curation" AND "journalism"; "content curator" AND "journalism"; "curation" AND "journalism"; "journalistic curation"; "curation" AND "news"; "news curation". 
"curación de contenidos" AND "periodismo"; "curador de contenidos" AND "periodismo"; "curaduría de contenidos" AND "periodismo"; "curación" AND "periodismo"; "curaduría" AND "periodismo"; "curación periodística"; "curaduría periodística"; "curación" AND "noticias"; "curaduría" AND "noticias".

As the list in Spanish shows, we have used the terms "curación" and "curaduría", which are the two mostly commonly adopted translations of the English word "curation".

b) Second, supplementing the academic search above with a search of professional sources, because there is a significant output on the subject in professional blogs and publications. To monitor information, we set up alerts in the platforms of both Google Alerts and Talkwalker Alerts using the search terms listed above and in social media using monitoring tools like Hootsuite and Tweetdeck.

Data collection took place between September 2017 and February 2018.

To supplement the literature review, we have also analysed the content of a sample of journalistic products in which an explicit use of news librarianship or journalistic content curation was identified. The content analysis took into account the selection made by the authors in previous studies (GuaIlar, 2015; 2016; 2017a; 2017b).

Based on the literature review and the content analysis of journalistic products, the paper proposes:

- A conceptualization of content curation in journalism;

- A conceptualization of the relationships between the specialities of news librarianship and journalistic content curation on the basis of an examination of a set of features or facets for analysis, which will be set out in detail below; and

- A proposal for discussion on the implications of a convergence between journalistic content curation and news librarianship for media outlets and media professionals.

\section{The bibliography on news librarianship and content curation in journalism}

\subsection{News librarianship}

The term "news librarianship" identifies an academic or professional discipline or speciality that is well known internationally, comes from a long-standing tradition and has left a large academic footprint. The speciality is also known academically as "journalistic documentation" or "media librarianship". Because the speciality has a strong professional presence in the media and particularly strong numbers in television, it has been addressed extensively in the literature. As noted earlier, a thorough compilation was not viewed as necessary for the purposes of the study. Instead, the analysis focuses on a selection of relevant papers.

As an overview, it should be noted first that there are a number of classic monographs that have been widely acknowledged and used as manuals in the speciality. Examples include works by Galdón (1989; 2002), Fuentes (1995) and Moreiro-González (2000). Also, more recent examples written along the same lines are the works by Rubio-Lacoba (2007) and Schopflin (2008). Two other comprehensive studies are also of interest: the first is an analysis of acade- mic output on the subject of news librarianship by Guallar (2003), while the second, which is by Sánchez-Vigil, Marcos-Recio and Olivera-Zaldua (2015), examines the main topics, research methods, authors and journals.

One of the foremost definitions of news librarianship comes from Codina (2000, p. 49):

"set of information sciences and techniques used to manage the following aspects of information on current events: a) its production, b) an increase in its quality, c) its storage and preservation, and d) its distribution and reuse".

Particularly important for the present study is the literature on the evolution of news librarianship in the past decade (since 2008), which is especially relevant for a traditional speciality that has recently undergone upheaval and major change.

\section{A relationship can readily be established between the functions, activities and products linked to the practice of $\mathrm{cu}$ - ration and the functions, activities and products linked to librarianship}

Looking at the studies that address the developments and trends in news librarianship, several authors have analysed the changes and evolution of the speciality's traditional functions and the relationship between news librarians and journalists in the newsrooms of media outlets (Micó-Sanz; Masip; García-Avilés, 2009; Rubio-Lacoba, 2010; Marcos-Recio; Edo, 2015). These changes have been occurring amid a growing crisis in the print media and in the functions of news libraries from their high point in the 1990s to today's staff cutbacks and questioning among news organizations, especially the print media (Paul, 2002; 2009). The title of the last of two cited articles by Nora Paul makes the situation perfectly clear: Elegy for the news library.

In response to the situation identified in the specialized literature and in descriptive studies of news librarians and media libraries (Marcos-Recio; Sánchez-Vigil; Serrada-Gutiérrez, 2009; Sánchez-Vigil; Marcos-Recio; Olivera-Zaldua, 2009; Guallar 2011b; Orero; Cebrián-Enrique, 2014; Meléndez-Malavé; Hirschfeld-Suárez, 2016), a variety of proposals have been put forward to bring the speciality of news librarianship up to date. The proposals include:

- Emphasizing the creation or co-creation of news content aimed directly at the audience (and not merely as an aid or support to the work of journalists), as an avenue for the growth, specialization and increased contribution of news librarians. This is the case with so-called "news documentary products" such as the anniversaries of events, biographies, timelines, archives of feature stories and so forth, and it concerns not only the field of print and digital media (Rubio-Lacoba, 2010; Guallar, 2011a) if we are talking about the profile of the "news librarian as textual co-producer" (García-Gutiérrez; Martínez-Ávila, 2014), but also the area of audio-visual media (Giménez-Rayo; Guallar, 2014; Rubio; Guallar, 2014), although some question marks hang over the actual extent of the latter 
(Micó-Sanz; Masip; García-Avilés, 2009; López-de-Quintana, 2014);

- Adapting the classic tasks of document analysis to the context of the internet and news tagging for digital media (Rubio-Lacoba, 2012);

- Achieving a greater involvement of library and information professionals in the use of social networks as information sources and communication channels (Guallar, 2012; Marcos-Recio; Edo, 2015); and

- Training newsroom users on digital technologies and document searches (Giménez-Rayo, 2012).

Although the professional sector of media librarians and their emergence in the academic literature is important, we must not forget that librarianship and its variants or particular concerns, such as verification, have been and remain crucial elements of the professional work of journalists. Thus, independently or in addition to its use by news librarians, journalistic documentation is also associated with the job of journalists (who are increasingly autonomous and do not receive help from librarians) in relation to the consultation, search and verification of information of all kinds. These issues are addressed in recent literature aimed at journalists (e.g., Cobo, 2012; Noguera-Vivo, 2015), and a key reference work on the subject is The verification handbook (Silverman, 2015).

The media environment has not yet witnessed the emergence of the news curator as a figure distinct from the journalist, whereas in its day the news librarian did become distinct from the journalist

In addition, some recently established journalistic specialities bear a relation to the tasks traditionally associated with library and information science, such as data journalism and fact-checking (Peiró; Guallar, 2013; López-García; Rodríguez-Vázquez; Álvarez-Gromaz, 2016; López-García; Toural-Bran; Rodríguez-Vázquez, 2016; Greenberg, 2017). This underscores the relevance of work done in the media by multi-disciplinary teams in which more technology-oriented job profiles, such as software engineers and SEO specialists, are gaining prominence.

\subsection{Content curation in journalism}

To address content curation in journalism, we must start by reviewing the concept of the term itself. As a recently emerging term, "content curation" first appeared in academic publications in the second decade of the twenty-first century, shortly after coming into use in the professional sector.

Its origin is usually dated to 2009, with the publication of the article Manifesto for the content curator (Bhargava, 2009). As we will soon see, however, various authors were already talking about curation at the time or even slightly earlier in ways that were similar to Bhargava (McAdams, 2008; Jarvis, 2008). In his "Manifesto", Bhargava, a marketing expert and professor, identifies the need for a new professional speciality in an information environment like that of the internet, which is characterized by content saturation, in order to select the most relevant content for a given audience. As Bhargava writes:

"A content curator is someone who continually finds, groups, organizes and shares the best and most relevant content on a specific issue online" (Bhargava, 2009).

While algorithms shape the system that people most commonly use to filter and access the vast amount of information on the internet, Bhargava points out that algorithms alone are not enough. Specialists are required to bring order to the chaos and to the excessive amounts of content and make sense of all the existing digital information.

The concept has spread rapidly in the second decade of the twenty-first century, extending out from the marketing sector to other disciplines and professional fields like library and information science, journalism, corporate communications and education, to name but a few. After Bhargava, the leading disseminators of the speciality include Robin Good, Steven Rosenbaum, Pawan Deshpande and Michael Bhaskar (Good, 2010; 2018; Rosenbaum, 2011; Deshpande, 2015; Bhaskar, 2016). In addition, a broad definition of the concept has been proposed by Guallar and Leiva-Aguilera:

"Content curation is a system used by a specialist, a content curator, on behalf of an organization or individual. It consists of continuously searching for, selecting, making sense of and sharing the most relevant content from several online information sources about a specific topic or set of topics and a specific area or set of areas. The content is chosen for a specific audience either online or in other contexts, such as an organization, has added value and therefore engages its audience/users" (Guallar; Leiva-Aguilera, 2013).

If we accept this definition and speak of an activity that focuses on searching for, selecting, making sense of and sharing information from a variety of sources, we can understand the job of the content curator as one of the professions or activities that straddles communication and library and information science (Guallar; Leiva-Aguilera, 2013).

McAdams (2008) was the first of several authors to look specifically at what the new approach contributes to journalism. The relevant terms used in the literature are: "content curation in journalism" (e.g., Cappelletti-Júnior; Domínguez-Quintas, 2014) and "journalistic curation" (Díaz-Arias, 2015).

Below is an overview of the main contributions that have been identified (the order is chronological, based on the earliest published work of each author):

- McAdams (2008), as noted earlier, is the author of a ground-breaking text that posits the need for curation in journalism on the internet and extends the functions currently performed by museum curators to digital media, such as selecting the most representative examples, offering context, organizing the resulting body of work and contributing their own expertise.

- Jarvis, one of the gurus of the new journalism, gives curation a highly prominent role in his proposals for the future of the profession. Like McAdams, he was already 
speaking of the need to introduce the idea of curation into journalism in 2008 (Jarvis, 2008). In one of his bestknown books, which was published in Spanish as El fin de los medios de comunicación de masas (Jarvis, 2015), he identifies curation as the current mode of the exercise of "rigour" in journalism and he frames it as a role that must be played by the media in order to deliver "journalism as a service". In his view, the curator-to be worthy of the title-" "must add judgment to be more than merely an aggregator" (Jarvis, 2015, p. 74).

- Jenkins (2010) lays out ten ways to use the platform Storify in journalism. Storify, which was unfortunately slated for shutdown in May 2018, was designed to do curation using a technique called storyboarding (Deshpande, 2013), that is, to combine content from various forms of social media in different formats (mashup) and to join them into a story (storytelling) that is typically chronological in nature (timeline). Some of Jenkins's ten ways to use Storify have gained wide traction, such as displaying a conversation or following live reactions to an event on social media. Others, while still appealing, have had less impact, such as collaborating with readers on a topic.

- Brewer (2011) is the author of a representative text from the early years in the introduction of the concept of curation. He takes the view that curation is an activity that journalists have always done (he says that "it is in their DNA"), even if they may not have called it curation.

- Guerrini (2013), in a seminal text, takes a contrary view, identifying curation as a redefinition of journalism as we have always known it. He stresses the importance of social media sources and user-generated content in the construction of new journalistic products. His concern is with the need to integrate the information flow from social media into journalistic practice with the help of a new storytelling platform, and his view is that the required integration is still at an early stage. He also focuses on the work of preserving digital content, especially content generated by social platforms, which he links to the archive work typically done by news librarians.

- Bradshaw has addressed journalistic content curation in a range of studies. He finds that curation has always been present in journalism:

"Curation is a relatively new term in journalism, but the practice is as old as journalism itself. Every act of journalism is an act of curation",

but his perception is that curation is much more important today. He also identifies a range of curation types and application examples in the media, such as list-based curation (listicles, Twitter lists), the selection of audio and video content, the narration of events using Storify, and so forth (Bradshaw, 2013). Bradshaw also takes an interesting approach to the obituary in a case study of curation-based journalistic pieces published on the death of David Bowie: a classic product type of news librarianship-a "news product" - is presented here as content curation (Bradshaw, 2016).

- Bakker (2014) regards curation as one of the new core competencies that the new digital journalist needs to ac- quire, together with other competencies relating to social media, such as community management.

- Cappelletti-Júnior and Domínguez-Quintas (2014) undertake a case study on the use of Storify by the Spanish daily El País. In their view, curation in journalism is closely linked to the practice of "collaborative storytelling", with the timeline being one of its most distinctive features and Storify offering one of its most representative tools. In their study, they identify a range of uses for Storify:

"to collect and group different opinions on a topic; to stimulate dialogue among users, and between users and the newspaper; to foster online discussions; to construct a detailed timeline of events; and to provide an alternative perspective on news events drawing on the perceptions of the main characters and others".

- Guallar has addressed the subject on several occasions and draws a distinction (Guallar, 2014) between what may be regarded as generic and specific identifiers of the concept of journalistic content curation. In the case of generic identifiers, he finds that curation adds nothing new to the work of journalists and news librarians because it is essentially what they have always done. (This is the view that we have identified as representative of the early years in which the term "curation" first appeared.) In the case of specific identifiers, however, he begins to investigate more closely and develops his findings in subsequent studies. Ultimately, he proposes a taxonomy of journalistic articles produced through content curation and he analyses a range of examples in terms of their features or facets, such as the type of sources used, the time frame of the curated information and the characterization (or sense-making) techniques employed (Guallar, 2015; 2016; 2017a; 2017b).

- Díaz-Arias (2015) takes the view that

"curation is a function that, together with traditional reporting and publishing, makes up the new journalism".

He highlights its crucial role in organizing and interpreting the public sphere, which is splintered at present into several parallel conversations: the media sphere, the personal sphere, the sphere of social media and so forth.

- Thorson and Wells (2015) point out that news items in today's digital information ecosystem circulate via curated flows involving journalistic curation, news consumers, their social networks, corporate communicators and algorithms.

- Noguera-Vivo (2015; 2016) applies Bhargava's initial take on curation to journalism in its current state, noting the importance of curation as an emerging competency for the journalist amid the paradigm shift affecting media today, from a lack of information to information overload. The second of the cited texts also provides an interesting overview of the literature on the subject and proposes a taxonomy of journalistic metamedia.

- Cui and Liu (2017) carry out a content analysis of 630 articles published by three newspapers of different characteristics - The New York Times, Vox and The Huffington Post - to identify their use of curation. The authors provi- 
de a thorough description of the practices of journalistic curation based on three parameters of analysis: internal or external content; types of characterization (they find three: contextualization, citation and interpretation); and types of sources (official, corporate, news sources, NGOs, members of the public, databases and online communities).

- López-Meri and Casero-Ripollés (2017) analyse how journalists use curation as one of their strategies to create or strengthen their personal brand. The authors identify the following practices of curation among journalists: recommending their own content, the content of competing journalists, the content of non-media actors, or alternative content to the coverage in the media; and verifying data and information, and dispelling rumours.

- Bruns (2018) addresses the relationship between curation and news from a perspective that differs from the one explored here: he analyses news curation done by the users of social media platforms (i.e., non-professional social curation) and its relationship to journalism as it broadens the conception of the global agenda.

- Rojas-Torrijos and González-Alba (2018) examine one of the most typical products of content curation in journalism, the newsletter, and analyse its use by three Spanish dailies.

- Lastly, Codina (2018) regards content curation as a tool to be used in the service of any mode of quality journalism, from solutions journalism to investigative journalism. He poses the following definition of content curation for journalists:

"Content curation in the area of mass media is the activity carried out by the journalist or communicator in connection with the (1) search, (2) monitoring and management, (3) selection, (4) analysis and verification and (5) publishing of information appearing on the internet, with the aim of producing or enriching journalistic products. This effort entails the (6) dissemination of such products through digital platforms such as themed blogs, social networking accounts and mass media sites".

\section{News librarianship and journalistic content curation: characteristics and convergence}

Looking at the literature discussed in the previous section and the main evolving trends in the media, a number of key points become apparent.

\section{In terms of news librarianship}

a) it has traditionally played an important role in journalism;

b) the recent crisis among the professional sector specializing as media librarians is the result of at least two causes:

- the plight of the media industry, especially print media, in the past decade, resulting in job cutbacks in media companies and

- the declining weight given to the speciality of news librarianship in digital newsrooms in favour of more technological professional disciplines;

c) it is now a widespread phenomenon that journalists them- selves are directly taking on news research tasks in an information environment in which the high volume of content moving through social media is gaining major importance.

\section{In terms of content curation in journalism:}

a) a variety of specialists identify curation as enormously important in the development of digital journalism in the twenty-first century and

b) a relationship can readily be established between the functions, activities and products linked to the practice of curation and the functions, activities and products linked to librarianship: one clear example is the search for and verification of external information.

In light of the key points identified above, the aim of the present study, as we noted earlier, is to analyse the relationship between the two specialities and consider their convergence.

We observe a notion of curation/librarianship that would make no distinction in the time frames of content: retrospective, recent, current and real-time information

\subsection{Definition of content curation in journalism}

Prior to an analysis of the essential characteristics of curation and librarianship, it seems appropriate to stake out a definition of journalistic curation or content curation in journalism based on the definitions examined earlier Guallar; Leiva-Aguilera 2013; Codina, 2018):

Journalistic content curation or content curation in the media area is a complex set of activities that include: 1) search and monitoring, 2) selection, 3) analysis and verification, 4) management and publishing, and 5) characterization or sense-making of the information published online. This involves the 6) dissemination of such products through digital platforms such as media sites, blogs and other social media.

This proposal combines a definition of content curation with the process steps of curation in earlier definitions that have integrated curation into the media area. It emphasizes crucial features of journalistic practice, such as verification activities, and it specifies the chief types of product that result from the activity.

\subsection{Essential characteristics of news librarianship and content curation in journalism}

Table 1 provides a summary of the core characteristics of the two specialities based on a number of features or facets for analysis:

- Time frame of the information

- Information origin

- Source types

- Core activities

- Chief products resulting from the activity

- Professional profiles 
Table 1. Core action areas in news librarianship and content curation in journalism

\begin{tabular}{|l|l|l|}
\hline \multicolumn{1}{|c|}{ Facets for analysis } & \multicolumn{1}{|c|}{ News librarianship } & \multicolumn{1}{c|}{ Content curation in journalism } \\
\hline Time frame of information & Retrospective and recent information & Recent, current and real-time information \\
\hline Information origin & Internal + external information & External information \\
\hline Source types & $\begin{array}{l}\text { Archive of own media, official websites, } \\
\text { digital press }\end{array}$ & Social media (Twitter, YouTube, blogs...), digital press \\
\hline Core activities & $\begin{array}{l}\text { Search, selection, treatment (document } \\
\text { analysis, preservation) }\end{array}$ & $\begin{array}{l}\text { Search and monitoring, selection, characterization or sense-making, } \\
\text { and sharing or distribution of content }\end{array}$ \\
\hline Products & $\begin{array}{l}\text { Timelines; biographies; anniversaries; } \\
\text { feature stories based on archive; } \\
\text { general support for a range of genres }\end{array}$ & $\begin{array}{l}\text { Real-time accounts of events; articles using a mashup of sources; } \\
\text { reporting on social media; recommendations in social media; newslet- } \\
\text { ters; general support for a range of genres }\end{array}$ \\
\hline Professional profiles & $\begin{array}{l}\text { News librarians or researchers, journalists, } \\
\text { communicators }\end{array}$ & Curators, journalists, communicators \\
\hline
\end{tabular}

For each facet, the table indicates which characteristics are most common or predominant based on what has been established in the bibliography.

Below is a more explicit look at each of the facets listed above, together with their characterization as they relate to news librarianship and content curation in journalism:

\subsubsection{Sources: time frame, origin and source types}

\section{News librarianship}

Traditionally, news librarians have worked essentially with retrospective information (published in the preceding months or years) and, to a lesser extent, with recent information (published in the past few days). They have drawn largely on the archives of their own media outlet, but they have also turned to a variety of outside sources, most notably official ones. Within the latter group, institutional and statistical sources are most common (Guallar; Cornet, 2004; Orero; Cebrián-Enrique, 2014; Cui; Liu, 2017).

\section{Content curation in journalism}

In the current context of social media, a good deal of information circulates through a variety of social media channels, resulting in diverse flows and discussions that sometimes intersect and get shared. Searching for and selecting information from the vast digital universe is the primary natural ground for the "new" journalistic curation, whose main focus is on external content. In terms of time frame, current information (from the last few hours) and real-time information are most prevalent, while the most common source type is information published or circulating on social media (Jenkins, 2010; Guerrini, 2013; Bradshaw, 2013; 2016; Cappelletti-Júnior; Domínguez-Quintas, 2014; DíazArias, 2015; Guallar, 2017b; Cui; Liu, 2017).

\subsubsection{Core activities}

\section{News librarianship}

The typical activities of news librarianship have tended to be described in terms of the so-called "document chain", which consists of the following activities:

- the input and selection of information in an information unit, documentation service or archive,

- treatment and management of information, including its storage and archiving, and
- document search or output.

In practice, the activities of media libraries can be divided into two broad groups: the first is content management, particularly document analysis, while the second is searching for internal and external content. They also perform complementary activities, which may include sales and distribution, product creation or co-creation, and more (GuaIlar, 2011b; Caldera-Serrano; Arranz-Escacha, 2012; Inarejos; Guallar, 2015).

\section{Content curation in journalism}

The 4S's method proposed by Guallar and Leiva-Aguilera (2013) provides an explanatory framework for grouping the activities of a typical curation process into four stages:

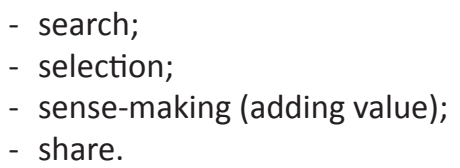

Taking a closer look at some of the activities in the four stages in terms of their specific relevance or their relationship to librarianship, we find the following:

- Monitoring (which is included in search, the first stage in the method) must be emphasized as a highly typical aspect of curation (Codina, 2018). While it can also play a part in librarianship, monitoring is core to curation. This is apparent from the existence of an entire software industry dedicated to monitoring content in social media.

- A detailed list of curation activities (Good, 2010) features a number that are close to the activities associated with librarianship, such as content tagging, which is equivalent to document analysis in news librarianship, and adding value at the sense-making stage, which can be compared to the previously mentioned creation or co-creation of products.

- The verification of information and the dispelling of rumours is another core curation activity related to librarianship that has become hugely important since the recent emergence of the issue of fake news (López-Meri; Casero-Ripollés, 2017).

Lastly, while they may only occasionally appear in the consulted literature, the tasks of preserving digital content are also attributed by some authors to the work of curation (Guerrini, 2013). 


\subsubsection{Products}

\section{News librarianship}

In the case of news librarianship, the products have one of two fundamental aspects:

a) they can give support to practically any journalism genre, ranging from interviews to beat reporting and investigative journalism, or

b) they can constitute a product in their own right. Included in the second group are so-called "documentary products", such as timelines, biographies, anniversaries of events, etc. (Codina, 2000, Guallar, 2011a; Giménez-Rayo and Guallar, 2014).

\section{Content curation in journalism}

In the case of curation, a parallel can be drawn with the fundamental aspects of the products of news librarianship. For curation, however, the two aspects are: a) curation can give support to practically any news product and b) curation can produce, or play a key or leading part in producing, the following products: real-time accounts or tracking of events; pieces constructed out of a combination of sources (mashup); reporting on social media; regular content recommendations on social media; and newsletters drawing on current news items published on social media and other sources and addressing any topic, from politics to technology (Jenkins, 2010; Bradhsaw, 2013; Guerrini, 2013; Cappelletti-Júnior; Dominguez-Quintas, 2014; Guallar, 2017a; 2017b; Cui; Liu, 2017; López-Meri; Casero-Ripollés, 2017; Good, 2018; Rojas-Torrijos; González-Alba, 2018).

While it is not very common in the literature, some authors also identify products that were once typical of librarianship, but are now products of curation too (Bradshaw, 2016, Guallar, 2017b). We will return to the subject in subsection 4.3.3.

\subsubsection{Professional profiles}

\section{News librarianship}

A sizeable overlap exists between the professional profiles for the two specialities. For instance, when the speciality of content curation began to make inroads in the fields of news librarianship and journalism, both news librarians and journalists took the view that the new speciality was very close to their traditional jobs, though the perspective of each profession had its own distinct or differential nuances (Brewer, 2011; Guallar, 2014; Díaz-Arias, 2015).

In the case of news librarians or researchers, the differential nuances revolve around a greater emphasis on searching for, verifying, selecting and managing content, while the nuances for journalists focus on the production of content using pre-existing content:

"Journalists have always searched for and selected sources, but with the aim of editing them to produce new information in a piece of news they write" (Díaz-Arias, 2015, p. 66).

The profiles associated with news librarianship can be ranked in order of importance as news librarian or researcher, journalist and, from a generic viewpoint, communicator.

\section{Content curation in journalism}

As for journalistic curation, the differential nuance noted above tends to disappear, because the journalism professional engaged in curation (the journalistic curator) should be involved in all four stages of the process, not only in searching for and selecting content (tasks more typical of news librarians), but in carrying out characterization or sense-making and dissemination (tasks more typical of journalists).

For reasons of symmetry, the top profile in the case of curation is curator, followed by journalist and communicator.

Interestingly, the media environment has not yet witnessed the emergence of the journalistic curator or the news curator as a figure distinct from the journalist, whereas in its day the news librarian did become distinct from the journalist. This is an intriguing point for discussion in the proposed convergence between news librarianship and journalistic content curation to which we will return in the next section (4.3.4).

Content curation in journalism can be understood as an updated form of news librarianship in an age of social media and user-generated content

\subsection{Convergence between news librarianship and content curation in journalism}

The aim of this section is to consider a convergence between the two approaches of "classic" news librarianship and "new" journalistic content curation.

\subsubsection{Sources}

With respect to sources, content curation sprang up in close relation to the social media ecosystem, social networks and user-generated content, although it cannot be confined to them (Codina, 2018). While timeless and retrospective content may not be the most representative or common forms treated in content curation, they have been present since the term was first used. This is apparent in well-known products such as the website "Brain Pickings", created by the journalist and content curator Maria Popova.

https://www.brainpickings.org

In addition, from the vantage of news librarianship, it appears natural to expand the focus by starting from the viewpoint of classic news librarianship, which revolves around the search for, selection and treatment of information from traditional sources (a media outlet's own archive, official sites, digital press), and broadening out to encompass the search for, selection and treatment of information originating from internet sources in general and social media more specifically.

A concrete example of such an expanded focus appears in an article posted on the Verne blog of the Spanish daily EI País, which is analysed in Guallar (2016): the article in question blends official information sources typical of news librarianship with reactions to the news appearing in social media, which are characteristic of curation.

https://goo.gl/ahx8KV 
Table 2. Proposal for the characterization of news librarianship and journalistic curation

\begin{tabular}{|l|l|}
\hline \multicolumn{1}{|c|}{ Key aspects } & \multicolumn{1}{c|}{ News librarianship and content curation in journalism } \\
\hline Time range of information & $\begin{array}{l}\text { Retrospective, recent, current and real-time information. Forward-looking information through monitoring and } \\
\text { alerts }\end{array}$ \\
\hline Information origin & Internal and external information. Information produced by social actors and user-generated content \\
\hline Source types & Archive of own media outlet, official websites, digital press, social platforms (Twitter, blogs, YouTube etc.) \\
\hline Core activities & $\begin{array}{l}\text { Search, monitoring, selection, treatment (tagging or document analysis), characterization or sense-making, and } \\
\text { sharing or distribution }\end{array}$ \\
\hline Products & $\begin{array}{l}\text { News documentary products (timelines, biographies, anniversaries of events, feauture stories based on archive, } \\
\text { investigative journalism, etc.), real-time accounts of events, articles using a mashup of sources, reporting on social } \\
\text { media, newsletters, recommendations in social media, etc. }\end{array}$ \\
\hline Professional profiles & Journalists, news librarians or researchers, curators, communicators \\
\hline
\end{tabular}

Another example appears in the previously mentioned study by Cui and Liu (2017), which considers content from the archive of the US daily The New York Times as a source for curation. The authors no longer refer to the work as news librarianship, but rather as journalistic curation.

As a result, we cannot draw a clear boundary line between journalistic curation and news librarianship based on their source types, if we take the view that it is natural to broaden the classic sources of news librarianship to cover the areas of social media and user-generated content and, at the same time, to expand the sources of journalistic content curation beyond the most common ones to encompass sources of all kinds.

\subsubsection{Core activities}

In an earlier section 4.2.2, this article proposed approaches to journalistic content curation and news librarianship that focused on core activities. Based on parallels drawn between the activities of news librarianship and a method of content curation known as the $4 S^{\prime}$ 's (Guallar; Leiva-Aguilera, 2013), the following point should be underscored:

News librarianship in its most classic formulation has primarily been based on the search for and selection of content (the first two of the $4 S^{\prime} s$ ) by news librarians and journalists. For some time now, various authors and, in practice, many professionals have been arguing that the job of news librarians should not be limited to these tasks, but should also involve taking part in the previously mentioned co-creation of products. The result would be to situate this aspect of their work in stage 3 of curation, or content characterization/sense-making. As for the last stage of the $4 \mathrm{~S}^{\prime} \mathrm{s}$ (sharing or distribution), it is already a matter of widespread concern among all media professionals, whoever actually performs the function.

We have also seen how the approaches offered by curation respond to news librarians' concerns over the management and preservation of digital content.

In short, there is sufficient common ground between the two disciplines to outweigh any potential points of difference. In essence, therefore, news librarianship and content curation in journalism cannot be distinguished by activities.

\subsubsection{Products}

The products of the two disciplines are sufficiently complementary in the broader context of journalistic activity as to give rise to a continuum that does not necessarily have clear-cut boundaries.

If a product resulting from curation must be

"newsworthy content that has either been (1) entirely or primarily produced through curation or (2) enriched and/or verified thanks to curation" (Codina, 2018),

then the term curation can readily be replaced in the definition by news librarianship. That is, even though the second point has been more common in classic news librarianship, the first point has also been very important and there have been calls to bolster it in recent years.

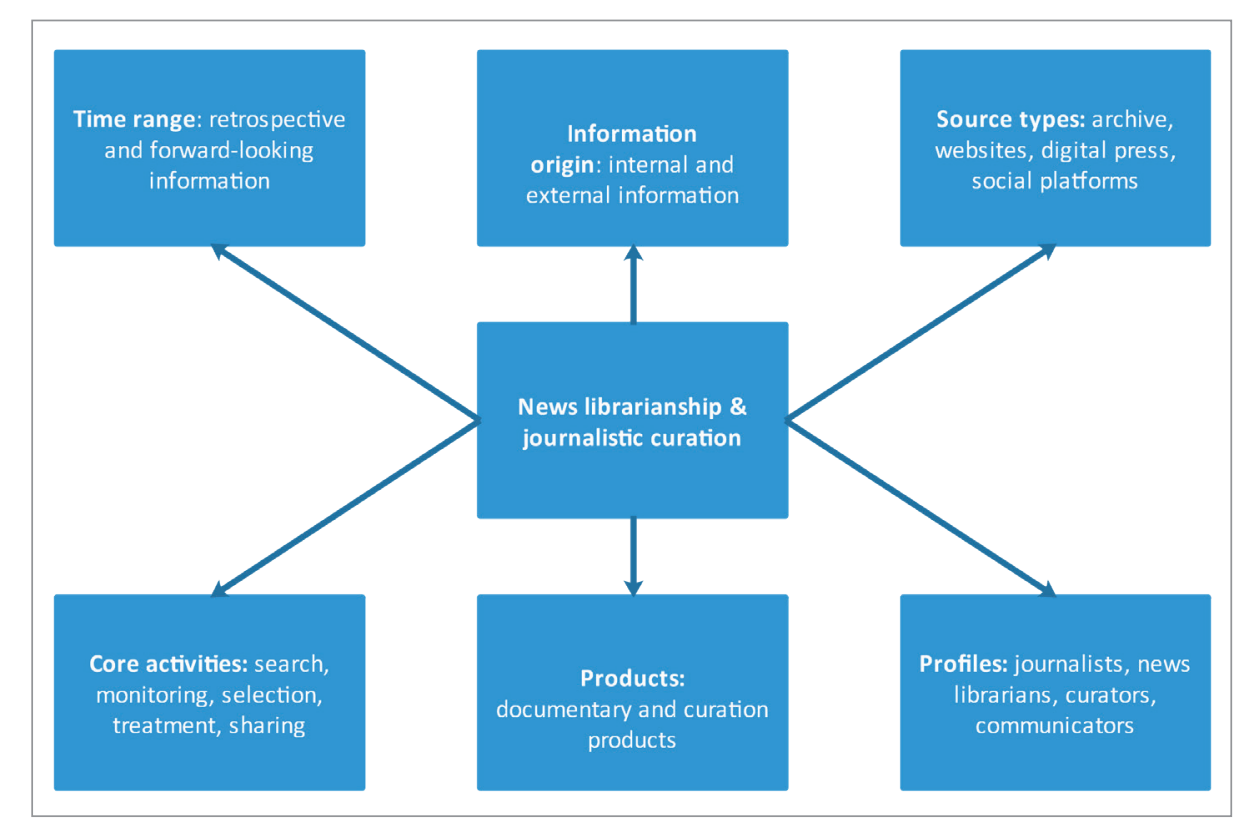

Figure 1. Diagram showing six key aspects of news librarianship and content curation in journalism 
An example of the convergence in products appears in the previously mentioned analysis of obituaries by Bradshaw (2016): a product typical of news librarianship can now be regarded as journalistic content curation if it incorporates sources of all kinds, not merely retrospective ones.

\subsubsection{Professional profiles}

As noted earlier, the involved professionals are journalists, news librarians or researchers, curators and communicators, with the last example being offered at a more generic level.

The analysis starts from the premise explored above that journalistic curation, like news librarianship before it, is becoming an activity and a core competency for journalism professionals.

For journalists, integrating the variety of information flows circulating on the internet is, as Díaz-Arias (2015) contends, an unavoidable necessity. Curation becomes a crucial function of the journalist in today's context, which tends toward dispersion and information chaos more than previous periods did. Given the diversity of sources, discussions and disparate content, the journalist is required to be a curator. It seems beyond doubt, therefore, that journalists must add the curation of information to their functions.

If we look beyond journalists as curators, however, can journalism develop a differentiated specialist in curation (the journalistic curator) in the same way that the figure of the documentation specialist (the news librarian) once came about?

We think it can, given the highly specific functions that must be performed, particularly in relation to verification issues and the critical nature of the information that must be curated. However, it remains an open question posited here as a theoretical hypothesis and as a proposal for potential adoption by professionals such as media librarians who happen to share the view put forward in this paper on the convergence of, and the blurring lines between, the two specialities.

Journalists and media librarians have all the skills and competencies needed to do journalistic curation

\section{Conclusions}

By looking at the two specialities in terms of our proposed facets for analysis - time scale of information, information origin, source types, core activities, products and professional profiles (see Figure 1)- we can position their relationship somewhere in the region between complementarity and convergence. If we think of them from a more traditional, conventional or static perspective, they are distinct activities that prove at best only partly complementary. But if we take a dynamic and evolutionary perspective, they are activities that appear to be converging.

From the fact that news librarianship focuses more on retrospective information and journalistic content curation has a greater focus on current or real-time information with a major component of monitoring, we can observe the desirability of moving toward a blended notion of curation/ librarianship that would make no distinction in the time frames of content and that could therefore work alike with retrospective, recent, current and real-time information.

Similarly, from the fact that news librarianship shows a greater concern with official online sources and journalistic content curation proves more concerned with social media sources and user-generated content, it appears equally necessary and appropriate to move toward a shared interest in sources of both kinds and to broaden the spectrum to include source types that did not previously receive consideration from classic news librarianship.

The proposition therefore is that, despite the differences and subtleties that we have sought to reflect along different dimensions of analysis, it is clear that there are very important points of intersection between the two disciplines and that their coming together or convergence is desirable.

To some extent, content curation in journalism can be understood as an updated form of news librarianship in an age of social media and user-generated content. From this vantage, it can be argued that content curation is the new librarianship.

Following the same logic, content curation may become indispensable to journalism in the twenty-first century just as it was said in the twentieth century that good journalism was impossible without news librarianship. While in no way belying the validity of this logic, it can also be said that good journalism is impossible without journalistic content curation. In addition, against the current backdrop of high volumes and information chaos online, librarianship/curation becomes, if anything, even more necessary.

This is why we attach so much importance to the implications of a blended notion of librarianship/curation for media professionals.

Journalists and media librarians have all the skills and competencies needed to do journalistic curation, which is what today's audiences require from journalism and news librarianship because they have become accustomed to digital content of all types and in all contexts.

The mission of librarianship/curation is to select and integrate diverse information flows circulating online in real time together with what is published in more traditional channels or has been published previously in the media as news products.

In this respect, journalistic curation is now much more than simply another option for journalism and media professionals. It is part and parcel of today's journalism, and even more so if the aim is to do quality journalism.

Much as the role of news librarianship in the media has been discussed for decades, it can now be said without fear of exaggeration that doing journalism will not be possible in the context of digital journalism in the twenty-first century without content curation. Or to put it another way, without content curation, it will not possible to do good journalism in the service of society. 
In conclusion, the main contributions of this study include a systematic literature review, case studies on the use of content curation and a proposal to clarify the concepts involved.

The proposal sets out theoretical and conceptual clarifications and contributions founded on the most robust scientific literature, with the aim of having an impact on the practice and professional development of the various professionals involved and on the teaching of the subject to future journalists, news librarians and communicators.

In addition, the ideas put forward in the study may have an influence on future lines of work and study, not only on those pursued by the authors, who will apply the conceptual underpinnings to the design of future research, but also on those undertaken by other research groups, who can build on the clarifications presented here.

Without content curation, it will not possible to do good journalism in the service of society

\section{Notes}

1. This article was written as part of the project "Creación and contenido interactivo en la comunicación de información audiovisual: audiencias, diseño, sistemas y formatos" CSO2015-64955-C4-2-R (Mineco/Feder), from the Spanish Ministry of Economics and Competitiveness, and from the consolidated research group in culture and digital content called "Cultura i Continguts Digitals" 2017 SGR 422.

2. Some examples from Guallar 2017a; 2017b, are:

- "El 'ciberyihadismo' en ocho preguntas clave". El español, $17 / 11 / 2015$.

http://www.elespanol.com/ciencia/20151117/79992036_0. html

- "Radiografía de la \#thinspiration, una peligrosa apología de la delgadez extrema". El diario.es. Hoja de router, 19/06/2015.

http://www.eldiario.es/hojaderouter/internet/thinspirationthinspo-anorexia-bulimia-internet-Twitter_0_399310527. html

- "Los 7 vídeos de Les Luthiers que nos hicieron reír hablando de ciencia y filosofía". El país Verne, 21/08/2015. https://goo.gl/Wrpy8D

- "Antologia del \#PressingCUP: els millors tuits, articles i vídeos crítics amb l'esquerra independentista". Crític, 22/11/2015.

http://www.elcritic.cat/actualitat/antologia-del-pressingcupels-millors-tuits-articles-i-videos-critics-amb-esquerraindependentista-6811

- "Batalla de hashtags en el Hemiciclo: \#HayFuturo contra \#LaEspañaReal”. El mundo, 24/02/2015.

http://www.huffingtonpost.es/2015/11/21/tuitsbernabeu_n_8617862.html?utm_hp_ref=spain
- "Série d'attaques terroristes à Paris, au moins 120 morts, état d'urgence décrété". Liberation, 13/11/2015.

http://www.liberation.fr/france/2015/11/13/fusilladedans-le-10e-arrondissement-de-paris_1413313

\section{References}

Bakker, Piet (2014). “Mr. Gates returns: Curation, community management and other new roles for journalists". Journalism studies, v. 15, n. 5, pp. 596-606.

Bhaskar, Michael (2016). Curation. The power of selection in a world of excess.

http://www.curationthebook.com

Bhargava, Rohit (2009). "Manifesto for the content curator: The next big social media job of the future?". Rohit Bhargava.com, Sept. $30^{\text {th }}$.

http://www.rohitbhargava.com/2009/09/manifesto-forthe-content-curator-the-next-big-social-media-job-of-thefuture-.html

Booth, Andrew; Sutton, Anthea; Papaioannou, Diana (2016). Systematic approaches to a successful literature review. London: Sage.

Bradshaw, Paul (2013). "Journalism *is* curation: Tips on curation tools and techniques". Online journalism blog, Sept. $30^{\text {th }}$.

http://onlinejournalismblog.com/2013/09/30/curationtools-tips-advice-journalism

Bradshaw, Paul (2016). "Curation is the new obituary: 8 ways media outlets marked Bowie's life and death". Online journalism blog, Jan. $11^{\text {th }}$.

http://onlinejournalismblog.com/2016/01/11/curation-isthe-new-obituary-8-ways-media-outlets-marked-bowieslife-and-death

Brewer, David (2011). "Content curation is in the DNA of all journalists". Media helping media, August $17^{\text {th }}$.

http://www.mediahelpingmedia.org/training-resources/ social-networking/636-content-curation-for-journalists

Bruns, Axel (2018). Gatewatching and news curation: Journalism, social media, and the public sphere. New York: Peter Lang. ISBN: 9781433143984

https://es.slideshare.net/Snurb/gatewatching-and-newscuration-social-media-and-the-public-sphere

http://snurb.info/node/2308

Caldera-Serrano, Jorge; Arranz-Escacha, Pilar (2012). Documentación audiovisual en televisión. Barcelona: Editorial UOC, colección El profesional de la información, n. 13. ISBN: 9788490299821

Cappelletti-Júnior, Milton; Domínguez-Quintas, Susana (2014). "La curaduría de contenidos y la narrativa colaborativa en el ciberperiodismo: estudio del caso de Storify en el diario digital Elpais.com". Estudios del mensaje periodístico, v. 20, n. 1.

https://revistas.ucm.es/index.php/ESMP/article/view/45216

Cobo, Silvia (2012). Internet para periodistas: Kit de supervivencia para la era digital. Barcelona: Editorial UOC. ISBN 9788497889889 
Codina, Lluís (2000). "La documentación en los medios de comunicación: situación actual y perspectivas de futuro". En: López-Yepes, José (ed.). Teoría, historia y metodología de las ciencias de la documentación (1975-2000). I Congreso Universitario de Ciencias de la Documentación. Madrid: Universidad Complutense de Madrid, pp. 23-40.

http://webs.ucm.es/info/multidoc/multidoc/revista/ num10/paginas/pdfs/Codina.pdf

Codina, Lluís (2018). “Curación de contenidos para periodistas: definición, esquema básico y recursos". Barcelona: Facultad de Comunicación, Área de Formatos Digitales e Interactivos, Universitat Pompeu Fabra.

https://repositori.upf.edu/handle/10230/34369

Creswell, John W. (2012). Qualitative inquiry and research: Choosing among five approaches. London: Sage. ISBN 978 1412995306

Cui, Xi; Liu, Yu (2017). "How does online news curate linked sources? A content analysis of three online news media". Journalism, v. 18, n. 7, pp. 852-870.

https://doi.org/10.1177/1464884916663621

Deshpande, Pawan (2013). "Six content curation templates for content annotation". The curata blog, August $13^{\text {th }}$. http://www.curata.com/blog/6-content-curation-templatesfor-content-annotation

Deshpande, Pawan (2015). "The definitive guide to content curation". The curata blog, Jan. $15^{\text {th }}$.

http://www.curata.com/blog/the-definitive-guide-tocontent-curation

Díaz-Arias, Rafael (2015). “Curaduría periodística, una forma de reconstruir el espacio público". Estudios del mensaje periodístico, v. 21.

http://revistas.ucm.es/index.php/ESMP/article/view/51129

Ferran-Ferrer, Núria; Guallar, Javier; Abadal, Ernest; Server, Adán (2017). "Research methods and techniques in Spanish library and information science journals (2012-2014)". Information research, v. 22, n. 1, paper 741.

http://InformationR.net/ir/22-1/paper741.html

Fuentes, M. Eulàlia (ed.) (1995). Manual de documentación periodística. Madrid: Síntesis. ISBN: 9788477383048

Galdón, Gabriel (1989). Principios operativos de la documentación periodística. Madrid: Dossat. ISBN: 97884 23707706

Galdón, Gabriel (2002). Teoría y práctica de la documentación informativa. Barcelona: Ariel. ISBN: 97884 34412934

García-Gutiérrez, Antonio; Martínez-Ávila, Daniel (2014). "Formación crítica de documentalistas en medios de comunicación". El profesional de la información, v. 23, n. 5, pp. 493-500.

https://doi.org/10.3145/epi.2014.sep.06

Giménez-Rayo, Mabel (2012). "La documentación audiovisual en televisión en el mundo 2.0: retos y oportunidades". Trípodos, n. 31.

http://www.tripodos.com/index.php/Facultat_Comunicacio_ Blanquerna/article/view/39
Giménez-Rayo, Mabel; Guallar, Javier (2014). “Centros de documentación en televisión y productos documentales". El profesional de la información, v. 23, n. 1, pp. 13-25.

https://doi.org/10.3145/epi.2014.ene.02

Good, Robin (2010). "Real-time news curation - The complete guide. Part 4: Process, key tasks, workflow". Master newmedia, Sept. $19^{\text {th }}$.

http://www.masternewmedia.org/real-time-news-curationthe-complete-guide-part-4-process-key-tasks-workflow

Good, Robin (2018). "Content curation approaches: Types and formats". Content curation official guide, Febr. $12^{\text {th }}$. https://medium.com/content-curation-official-guide/contentcuration-approaches-types-and-formats-ae2b33fe6a18

Greenberg, David (2017). "Deciding what's true: The rise of political fact-checking in American journalism". Journal of communication, v. 67, n. 6.

https://doi.org/10.1111/jcom.12329

Guallar, Javier (2003). “Mètodes i tècniques de recerca en els articles de documentació periodística a Espanya (19972002)". BiD: textos universitaris de biblioteconomia i documentació, n. 11.

http://bid.ub.edu/11gualla.htm

Guallar, Javier (2011a). "La documentación en la prensa digital. Nuevas tendencias y perspectivas". En: III Congreso Internacional de Ciberperiodismo y Web 2.0, Bilbao, Universidad del País Vasco, 9-11 noviembre, pp. 52-68.

http://eprints.rclis.org/16326

Guallar, Javier (2011b). “Documentación fotográfica en la prensa. Casos de El país, El periódico y La vanguardia". El profesional de la información, v. 20, n. 4, pp. 392-398. https://doi.org/10.3145/epi.2011.jul.05

Guallar, Javier (2012). “Documentalistas de medios y redes sociales". Anuario ThinkEPI, v. 6, pp. 170-172.

https://recyt.fecyt.es/index.php/ThinkEPI/article/view/30411

Guallar, Javier (2014). “Content curation en periodismo (y en documentación periodística)". Hipertext.net, n. 12.

https://doi.org/10.2436/20.8050.01.16

Guallar, Javier (2015). "Curación de contenidos en los medios digitales". En: I Simposio internacional Xescom gestión de la comunicación, Facultad de Comunicación y Ciencias Sociales, Universidad de Vigo, Campus Pontevedra, 28 noviembre.

http://eprints.rclis.org/28614

Guallar, Javier (2016). "Curación de contenidos en el periodismo digital". En: Seminario Digidoc, Universidad Pompeu Fabra, Barcelona, 28 enero.

http://eprints.rclis.org/28866

Guallar, Javier (2017a). "Artículos de curación de contenidos. Categorías y ejemplos". Anuario ThinkEPI, v. 11, pp. 210-216.

https://doi.org/10.3145/thinkepi.2017.38

Guallar, Javier (2017b). “Content curation in digital media: Between retrospective and real-time information". In: Campos-Freire, Francisco; Rúas-Araújo, Xosé; Martínez-Fernández, Valentín; López-García, Xosé (eds.). Media and meta- 
media management. Advances in intelligent systems and computing, v. 503, p. 37-46. ISBN: 9783319460666

https://doi.org/10.1007/978-3-319-46068-0_6

Guallar, Javier; Cornet, Anna (2004). "Fuentes de información digitales en los centros de documentación de prensa: las bases de datos comerciales". El profesional de la información, v. 13, n. 2, pp. 107-117.

http://eprints.rclis.org/8446

Guallar, Javier; Ferran-Ferrer, Núria; Abadal, Ernest; Server, Adán (2017). "Revistas científicas españolas de información y documentación: análisis temático y metodológico". El profesional de la información, v. 26, n. 5, pp. 947-960.

https://doi.org/10.3145/epi.2017.sep.16

Guallar, Javier; Leiva-Aguilera, Javier (2013). El content curator. Guía básica para el nuevo profesional de internet. Barcelona: Editorial UOC, colección El profesional de la información, n. 24, 162 p. ISBN 9788490640180

Guerrini, Federico (2013). Newsroom curators \& independent storytellers: Content curation as a new form of journalism. Reuters Institute for the Study of Journalism, University of Oxford.

https://reutersinstitute.politics.ox.ac.uk/publication/ newsroom-curators-and-independent-storytellers

Inarejos, Lluís; Guallar, Javier (2015). “Centros de documentación de televisiones en Catalunya. Estudio de BTV, RTVE, TVC y 8tv". Cuadernos de documentación multimedia, v. 26. https://doi.org/10.5209/rev_CDMU.2015.v26.50629

Jarvis, Jeff (2008). "No news is no news". Buzz machine, Nov. $3^{\text {rd }}$.

https://buzzmachine.com/2008/11/03/no-news-is-no-news-2

Jarvis, Jeff (2015). El fin de los medios de comunicación de masas. Barcelona: Gestión 2000, 222 pp. ISBN: 978849875 4018

Jenkins, Mandy (2010). "10 ways journalists can use Storify". Zombie journalism, Oct. $21^{\text {st }}$.

http://zombiejournalism.com/2010/10/10-waysjournalists-can-use-storify

López-de-Quintana-Sáenz, Eugenio (2014). "Rasgos y trayectorias de la documentación audiovisual: logros, retos y quimeras". El profesional de la información, v. 23, n. 1, pp. 5-12. https://doi.org/10.3145/epi.2014.ene.01

López-García, Xosé; Rodríguez-Vázquez, Ana-Isabel; Álvarez-Gromaz, Lucía (2016a). "El fact checking como reclamo y como servicio en los cibermedios. Análisis de las experiencias de 'The Washington Post' y 'The Guardian'”. Telos, n. 13. https://goo.gl/bKKuV3

López-García, Xosé; Toural-Bran, Carlos; Rodríguez-Vázquez, Ana-Isabel (2016b). "Software, estadística y gestión de bases de datos en el perfil del periodista de datos". El profesional de la información, v. 25, n. 2, pp. 286-294. https://doi.org/10.3145/epi.2016.mar.16

López-Meri, Amparo; Casero-Ripollés, Andreu (2017). “Las estrategias de los periodistas para la construcción de marca personal en Twitter: posicionamiento, curación de contenidos, personalización y especialización". Revista mediterrá- nea de comunicación, v. 8, n. 1, p. 59-73. http://dx.doi.org/10.14198/MEDCOM2017.8.1.5

McAdams, Mindy (2008). "Curation and journalist as curators". Teaching online journalism, Dec. $3^{\text {rd }}$. http://mindymcadams.com/tojou/2008/curation-andjournalists-as-curators

Marcos-Recio, Juan-Carlos; Edo, Concha (2015). "Análisis de la nueva perspectiva de la documentación periodística en los medios de comunicación españoles". Revista general de información y documentación, v. 25, n. 2, pp. 389-423. https://doi.org/10.5209/rev_RGID.2015.v25.n2.51235

Marcos-Recio, Juan-Carlos; Sánchez-Vigil, Juan-Miguel; Serrada-Gutiérrez, María (2009). "Nuevos paradigmas periodísticos y documentales en los periódicos digitales: estudio de casos en España". Investigación bibliotecológica, v. 23, n. 49, pp. 43-65.

https://dialnet.unirioja.es/servlet/articulo?codigo $=3666747$

Meléndez-Malavé, Natalia; Hirschfeld-Suárez, Rocío (2016). "Situación de los centros de documentación en los medios escritos andaluces". El profesional de la información, v. 25, n. 4, pp. 606-615.

https://doi.org/10.3145/epi.2016.jul.10

Micó-Sanz, Josep-Lluís; Masip, Pere; García-Avilés, José-Alberto (2009). "Periodistas que ejercen de documentalistas (¿y viceversa?). Nuevas relaciones entre la redacción y el archivo tras la digitalización de los medios". El profesional de la información, v. 18, n. 3, pp. 284-290.

https://doi.org/10.3145/epi.2009.may.05

Moreiro-González, José-Antonio (coord.) (2000). Manual de documentación informativa. Madrid: Cátedra. ISBN 978 8437617985

Noguera-Vivo, José-Manuel (2015). Todos todo. Manual de periodismo, participación y tecnología. Barcelona: Editorial UOC. ISBN: 9788491160380

Noguera-Vivo, José-Manuel (2016). “Metamedios y periodismo: revisión panorámica de los nuevos cibermedios". El profesional de la información, v. 25, n. 3, pp. 341-350. https://doi.org/10.3145/epi.2016.may.03

Orero, Paz; Cebrián-Enrique, Bernardino J. (2014). “Criterios de evaluación y aplicación de fuentes de información web en centros de documentación periodística". El profesional de la información, v. 23, n. 6, pp. 612-617.

https://doi.org/10.3145/epi.2014.nov.08

Paul, Nora (2002). "Media libraries and new media”. Poynter Institute online, August, $26^{\text {th }}$.

https://www.poynter.org/news/media-libraries-and-newmedia

Paul, Nora (2009). "Elegía del centro de documentación de prensa". El profesional de la información, v. 23, n. 3, pp. 249254.

https://doi.org/10.3145/epi.2009.may.01

Peiró, Karma; Guallar, Javier (2013). "Introducció al periodisme de dades. Característiques, panoràmica i exemples". Ítem, n. 57, pp. 22-36.

https://www.raco.cat/index.php/Item/article/view/269701 
Ravitch, Sharon M.; Mittenfelner-Carl, Nicole C. (2015). Qualitative research: bridging the conceptual, theoretical, and methodological. London: Sage. ISBN: 9781483351742

Rojas-Torrijos, José-Luis; González-Alba, José-Antonio (2018). "La newsletter como producto periodístico en la búsqueda de nuevos lectores. Estudio de boletines de noticias de El País, El Español y El Independiente". adComunica. Revista Científica de Estrategias, Tendencias e Innovación en Comunicación, n. 15, p. 165-195.

https://doi.org/10.6035/2174-0992.2018.15.9

Rosenbaum, Steven (2011). Curation nation: how to win in a world where consumers are creators. New York: McGraw-Hill, 284 pp. ISBN: 9780071760393

Rubio, Albert; Guallar, Javier (2014). “Funcions del documentalista en un mitjà de comunicació audiovisual digital. Estudi de cas: RelTV". BiD: textos universitaris de biblioteconomia i documentació, n. 33.

https://doi.org/10.1344/BiD2014.33.18

Rubio-Lacoba, María (2007). Documentación informativa en el periodismo digital. Madrid: Síntesis, 143 pp. ISBN: 978 8497568784

Rubio-Lacoba, María (2010). “Documentalistas de prensa, ¿cuál es vuestro oficio?". El profesional de la información, v. 19, n. 6, pp. 645-651.

https://doi.org/10.3145/epi.2010.nov.11

Rubio-Lacoba, María (2012). "Nuevas destrezas documentales para periodistas: el vocabulario colaborativo del diario
El país". Trípodos, n. 31.

http://www.tripodos.com/index.php/Facultat_Comunicacio_ Blanquerna/article/view/38

Sánchez-Vigil, Juan-Miguel; Marcos-Recio, Juan-Carlos; Olivera-Zaldua, María (2009). "Influencia de la fotografía digital en los departamentos de documentación de prensa". El profesional de la información, v. 18, n. 3, pp. 278-283.

https://doi.org/10.3145/epi.2009.may.04

Sánchez-Vigil, Juan-Miguel; Marcos-Recio, Juan-Carlos; Olivera-Zaldua, María (2015). "Producción científica sobre comunicación y medios en las revistas de documentación". Revista española de documentación científica, v. 38, n. 4. https://doi.org/10.3989/redc.2015.4.1257

Schopflin, Katharine (ed.) (2008). A handbook for media librarians. London: Facet. ISBN: 9781856046305

Silverman, Craig (ed.) (2015). The verification handbook. European Journalism Centre.

http://verificationhandbook.com

Thorson, Kjerstin; Wells, Chris (2015). “How gatekeeping still matters: Understanding media effects in an era of curated flows". In: Vos, Tim P.; Heinderyckx, Francois (eds.). Gatekeeping in transition. Routledge, pp. 25-44. ISBN: 978 0415731614

https://goo.gl/teKXyX

Thyer, Bruce A. (2010). "Theoretical research" In: Thyer, Bruce A. (ed.). The handbook of social work research methods. London: Sage, pp. 468-492. ISBN: 9781412958400

\section{El profesional de la información
Servicio de traducciones al inglés http://www.elprofesionaldelainformacion.com/documentos/traducciones.pdf}




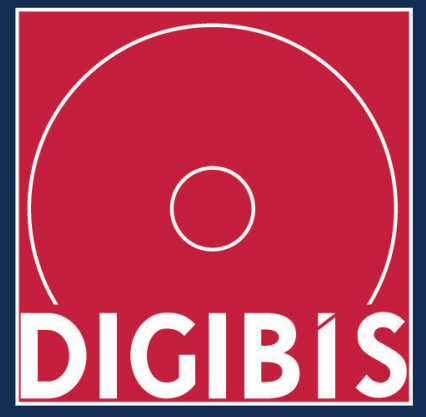

Nuestra vocación: contribuir a que el patrimonio cultural español sea preservado digitalmente y se difunda de la manera más amplia posible

Con metadatos ajustados a la normativa internacional

Aplicaciones Linked Open Data (LOD) con Reconciliación Semántica

Aplicaciones que pueden incorporar Recolector y Repositorio OAI-PMH

Aplicaciones pensadas y desarrolladas para hacer más eficiente y ágil el trabajo de los administradores y más comprensible para el usuario el acceso a los recursos catalogados. 